\title{
Financial Performance of Islamic and Conventional Mutual Funds in Indonesia Stock Exchange
}

\author{
M. Ridho Pratama \\ Department of Islamic Economics, \\ Faculty of Islamic Studies \\ Universitas Islam Indonesia \\ Yogyakarta, Indonesia \\ 14423245@students.uii.ac.id
}

Tulasmi

Department of Islamic Economics,

Faculty of Islamic Studies

Universitas Islam Indonesia

Yogyakarta, Indonesia

tulasmi@uii.ac.id

\author{
Martini Dwi Pusparini \\ Department of Islamic Economics, \\ Faculty of Islamic Studies \\ Universitas Islam Indonesia \\ Yogyakarta, Indonesia \\ martini.dwi@uii.ac.id
}

\author{
Rakhmawati \\ Department of Islamic Economics, \\ Faculty of Islamic Studies \\ Universitas Islam Indonesia \\ Yogyakarta, Indonesia \\ rakhmawati@uii.ac.id
}

\author{
Yuli Andriansyah \\ Department of Islamic Economics, \\ Faculty of Islamic Studies \\ Universitas Islam Indonesia \\ Yogyakarta, Indonesia \\ yuliandriansyah@uii.ac.id
}

\begin{abstract}
The purpose of this research is to analyze the comparison of performance between Islamic mutual funds and conventional mutual funds using the calculation of return, Sharpe, and Treynor and to find out which types of mutual funds are the best in 2015-2017. The analysis used in the research is a comparative descriptive method with a quantitative approach. The results of this research indicate that the majority of conventional mutual funds are superior to Islamic mutual funds in 2015-2017, although there are several types of Islamic mutual funds that are superior. Besides that, overall after a different test, it was shown that there were no significant differences between Islamic and mixed mutual funds, although some calculation methods showed differences.
\end{abstract}

Keywords: Indonesia Stock Exchange, Islamic mutual funds, Sharpe, Treynor

\section{INTRODUCTION}

One of the traded capital market instruments is mutual funds. Mutual funds are a container that is used to raise funds from the investor community to be invested in the securities portfolio by the investment manager. Mutual funds are present as a means to raise funds from people who have the desire to invest, but do not have so much capital, and do not have much expertise and time to calculate the risks of their investments [1-2].

Mutual funds have two sub categories, namely Islamic mutual funds and conventional mutual funds. Islamic mutual funds are mutual funds that are run based on the provisions and principles of Islamic law. In Islamic mutual funds there is a screening process and cleansing process. The screening process is the process of screening securities that are in accordance with Islamic law, for example selecting assets of companies that do not have illicit activities such as usury, gharar, gambling, production of illicit food or drinks, such as pork, liquor, cigarettes, and so on. While the cleansing process is the process of removing securities that are not in accordance with the Shari'a, so the profits generated from these securities must be issued and practiced by paying zakat [3-4].
Islamic mutual funds aim to guide investors who want to invest their funds in accordance with Islamic law. In fact, the existence of Islamic mutual funds will provide more investment choices for the community, especially Muslim investors. However, besides that, there are still concerns that Islamic mutual funds are not able to provide better returns than conventional mutual funds. This doubt arises because of the alleged lack of optimal allocation in the investment portfolio, which is caused by the screening process that limits investment, because the products that are the object of investment are only those that are in accordance with Islamic law [5].

Basically, Islamic mutual funds and conventional mutual funds are not much different. As explained above, Islamic mutual funds have different criteria than conventional mutual funds in general. The first difference lies in the selection of investment instruments. Islamic mutual funds only place their funds in instruments that are free from the practice of usury and practices that are not lawful according to Islamic law. The investment mechanism in Islamic mutual funds must not conflict with sharia principles. The operational mechanism of Islamic mutual funds between investors and investment managers is Wakalah, while between investment managers and investment users is Mudharabah [6].

Mutual funds are classified into four types, namely Stock Mutual Funds, Mixed Mutual Funds, Fixed Income Mutual Funds, and Money Market Mutual Funds. The four types of mutual funds are general mutual funds that are known by investors. The good or bad performance of portfolio investments managed by investment managers is influenced by investment policies and strategies carried out by the investment managers concerned.

Therefore a performance analysis of investment managers is needed that is good and thorough before making an investment. Mutual fund performance can be measured by only calculating based on total return or better yet by involving risk measurement. Performance measurement by involving risk factors provides more in-depth information for investors about the extent to which an outcome or 
performance provided by an Investment Manager is associated with the risks taken to achieve that performance [7],[8].

Mutual fund performance evaluation is a matter that must be considered in measuring the benefits and risks of each mutual fund. Mutual fund performance evaluation using performance measurement that takes into account the benefits and risks, namely Risk Adjustable Return (RAR). Some methods on RAR that are often used in measuring portfolio performance and international standards are Sharpe and Treynor Indexes [9].[10].

Research on the performance of mutual funds using the Sharpe and Treynor method has been carried out. In the research conducted by Agussalim et al. [11] the object was sharia and conventional stock mutual funds, whose performance measurement uses the Sharpe, Treynor, and Jensen methods. The results of the research state that there is no difference in performance between Islamic and conventional stock mutual funds when using the method of calculating return and sharpe, but there are differences when using the treynor and Jensen methods. This explains that each calculation with a different type of method will give different results.

The difference with this research is that the objects in this research were not only in the types of stock mutual funds, but also in mixed and fixed income mutual funds. The selection of the three types of mutual funds is based on the condition of mutual fund developments in early 2018, which shows that those who experience an increase in return are only money market mutual funds, while the other three types of mutual funds decline. So from that the researcher chose the three types of mutual funds to find out what factors influence the decline in the performance of the mutual fund. In addition, the method used for the calculation used in this research is only based on return, Sharpe, and Treynor.

This research discusses the comparative analysis of performance on Islamic mutual funds and conventional mutual funds in 2015-2017 to find out what types of Islamic mutual funds or conventional mutual funds that have better performance. The researcher uses the object of mutual funds in this research because mutual funds are one of the securities that are traded on the capital market with the least risk. This is to provide information to investors as a consideration in investing. This research can also be a reference in choosing the best stock mutual funds for prospective investors who are investing for the first time and for investors who have long invested in the capital market.

\section{LITERATURE REVIEW}

A number of researchers have compared the performance of Islamic and conventional mutual funds in both the Indonesian and international contexts. The literature review describes a number of previous researches, starting from cases in Indonesia followed by cases in other countries. Huda \& Hudori,[12] explains that there is no significant difference between the return of Islamic stock mutual funds. In addition, there is no difference in the risk of Islamic and conventional stock mutual funds. Likewise in terms of performance, there is no significant difference with the Sharpe, Treynor, Jensen, M2 measure, and T2 measure approaches during the period of January 2012 to December 2015. Hidayatul et al. [13] prove that conventional mutual funds have better performance than Islamic mutual funds if using the Sharpe, Treynor, and AUM growth methods. However, if using the Jensen method, Islamic mutual funds have better performance because they have higher average values than conventional mutual funds.

Putra \& Fauzie [14] analyzed how the performance between conventional and Islamic mutual funds using the ratio of Sharpe, Treynor and Jensen. The results of the research explain that the rate of return of Islamic mutual funds is better than conventional mutual funds. The risk of Islamic mutual funds is also smaller than conventional mutual funds. This proves, even though the investment portfolio in Islamic mutual funds is more limited, but still has a better return.

Riyadi et al. [15] measure the performance of Islamic and conventional stock mutual funds to find out which mutual funds can beat the market. The results of this research are that the performance of Islamic stock mutual funds is better than the performance of conventional mutual funds if analyzed based on Sharpe Ratio, Treynor Ratio, and Jensen Ratio. This is proven from the results of RAR analysis during the research period that only Islamic stock mutual funds have products that are able to outperform the market. Isnurhadi [16] analyzes stock mutual funds in Indonesia using the Sharpe ratio. This research explains that there are 3 stock mutual fund products that are able to outperform the JCI average return, namely Panin Dana Maksima, Panin Dana Prima, and Trimegah Kapital. These results are obtained by calculating the performance of each product using Sharpe Ratio.

Acma [17] analyzes mutual fund performance evaluations in Bangladesh by analyzing the benefits earned each month. The results of the research show that in Bangladesh, the mutual fund industry is at a stage of growth every year. From the analysis above, it can be noted that the growth of mutual funds does not have a better performance against volatility. Growth-oriented mutual funds are expected to offer benefits of diversification, timing and market selectivity.

Jakšić et al. [18] analyze the measurement of mutual funds performance included with case studies in Serbia. The research method used is descriptive quantitative. The research results were evaluating the performance of eight open mutual funds in Serbia for the period 2009-2012, by applying the Sharpe ratio $(S i)$, Treynor ratio $(T i)$, and Jensen or Alpha ( $\alpha i)$. According to the Sharpe ratio, seven of the eight funds analyzed have lower performance than benchmarks. The Treynor ratio for most funds is positive and is greater than the Treynor ratio for the Belex 15 benchmark, while the negative alpha index for all mutual funds is openly tested in Serbia. A significant negative alpha index value has been observed in the case of around $40 \%$ of the funds analyzed. The results clearly show that the Serbian mutual fund portfolio has a lower performance compared to the market portfolio.

Agarwal \& Mirza [19] describes the measurement of the performance of selected mutual funds based on risk and returns and compares the performance of the selected scheme with a benchmark index to see whether the scheme outperforms or performs poorly against benchmarks. This research assesses the performance of Indian mutual fund schemes using sharpe ratio, treynor ratio, Alpha and Value Jensen risk for a sample of 100 Indian mutual fund schemes. The research method used is a quantitative approach. The results of this research are the results of the sharpe ratio and 
the treynor ratio reflecting that 90 percent of the schemes have performed better than their benchmarks which reflect that during this period the funds have run quite well and have outperformed the market. Meanwhile, in the jensen method, returns generated by 79 schemes are adequately compensated for the average market return given by beta.

Bajracharya [20] analyzes the performance value of mutual funds in Nepal using the Sharpe and Treynor methods. The method used is a quantitative approach method. The results of the research show that mutual funds have not shown better performance than their benchmark indicators. Some of these funds have better performance than their systematic risk benchmarks, but with respect to the volatility of most funds, they have not performed better. In the sample, funds are not very diversified except for a number of mutual funds and because of their high diversification, they have reduced total portfolio risk whereas, other mutual funds have a low diversified portfolio and have more risks.

Alexandri et al. [21] explain the performance of Islamic mutual funds in Indonesia. The research method used is quantitative. The results of this research can be seen that the three independent variables studied were asset allocation policies for sharia stocks, asset allocation policies for Islamic bonds (sukuk), and asset allocation policies for mudharabah deposits which simultaneously affected the performance of Islamic mixed mutual funds. Bauer et al. [22] explain the analysis of ethical mutual funds compared to conventional mutual funds by measuring the performance of each mutual fund. The results of the research state that ethical mutual funds provide returns that are adjusted to the average risk that matches conventional funds during the 1998-2001 period. The equation of the research and the research of the authors both carried out an analysis of the performance of mutual funds, but the difference lies in the mutual fund object used in the calculation.

\section{MeTHODOLOGY}

This type of research is quantitative research by analyzing the performance of conventional mutual funds and active Islamic mutual funds in 2015 until 2017. The variables used in this research are Return mutual funds, Sharpe ratio, standard deviation, treynor ratio, and beta. In addition, this research uses comparative studies that is comparing the performance results of stock mutual funds between Islamic and conventional categories.

This research was conducted on mutual funds registered in the Financial Services Authority (OJK) in the period January 2015-December 2017. Data collection was taken from several websites related to capital markets and mutual funds, such as the Financial Services Authority www.ojk.go.id, Bareksa www .bareksa.com, Pusat Data Kontan pusatdata.kontan.co.id, Yahoo Finance, Infovesta www.infovesta.com and so on. The research was conducted starting from February-July 2018.

The population in this research are several Islamic mutual funds and conventional mutual funds from the category of money market mutual funds, stock mutual funds, mixed mutual funds, and fixed income mutual funds which are still actively traded in the research period, namely 2015-2017. The total number of mutual funds is 157 mutual fund products. While the sampling technique in this research used a purposive sampling method, which is choosing samples with the desired criteria.

These criteria include: 1) Several types of stock, mixed, and fixed income mutual funds which are listed in the OJK, and stated to be the most consistent according to Bareksa; and 2) Mutual funds NAB data during the research period. With these criteria, the samples for each will amount to: 1) Islamic and conventional stock mutual funds each taken 10 (ten) mutual funds; 2) Islamic and conventional mixed mutual funds are each taken 10 (ten) mutual funds; 3) Islamic and conventional fixed income mutual funds are each taken 10 (ten) mutual funds.

This research conducted a comparison of the performance of stock, mixed, and fixed income mutual funds between Islamic and conventional types. The performance is calculated based on the calculation of returns, sharpe, and treynor. Returns are profits generated by mutual funds taken based on the results obtained at the end of each month. Calculation of sharpe ratio is measured based on premium risk that is the difference from the average portfolio investment return with the average risk-free investment return then compared to the standard deviation. The calculation using the treynor method is actually not much different from the sharpe ratio. The difference lies only in the divider, which is to use a difference which is a systematic risk. This means that market risk is very influential in calculating performance with the Sharpe method. So in calculating performance, it will use the value of the index of each type of mutual fund, IHSG for stock mutual funds, mixed indexes for mixed mutual funds, and the bond index for fixed income mutual funds.

The data analysis technique used is descriptive quantitative. Data is processed in accordance with the definition of operational variable using descriptive statistics of average different tests with the help of SPSS and Microsoft Excel programs to record, calculate, and analyze. The analysis used was descriptive analysis of the normality test, and analysis of two independent t-tests sample or the ManWhitney test for non-parametric data.

\section{RESULTS}

\section{A. Differences in performance of Islamic and conventional stock mutual funds}

This different test is conducted to test a number of hypotheses, to find out whether there are differences in performance between Islamic stock mutual funds and conventional stock mutual funds. The results of the ManWhitney test are as follows:

It is known that the significance value (Asymp Sig) of the return on the stock mutual fund is 0.389. Because Significance> 0.05, Ho is accepted and H1 is rejected. So it can be concluded that there is no significant difference in the average return value between Islamic and conventional stock mutual funds.

It is known that the significance value (Asymp Sig) of the Sharpe calculation of the stock mutual fund is 0.019 . Because the significance $<0.05$ then $\mathrm{Ho}$ is rejected and $\mathrm{H} 2$ is accepted. So it can be concluded that there is a difference in the average of sharpe value between Islamic and conventional stock mutual funds. 
It is known that the significance value (Asymp Sig) of the return on the stock mutual fund is 0.597. Because the Significance $>0.05$ then $\mathrm{Ho}$ is accepted and $\mathrm{H} 2$ is rejected. So it can be concluded that there is no difference in the average of treynor value between the Islamic and conventional stock mutual funds.

\section{B. Differences in performance of Islamic and conventional mixed mutual funds}

This different test was carried out to test a number of hypotheses, to find out whether there were differences in performance between Islamic mixed mutual funds and conventional mixed mutual funds. The results of the ManWhitney test were as follows:

It is known that the significance value (Asymp Sig) of the return of the mixed mutual fund is 0.257 . Because the Significance $>0.05$ then $\mathrm{Ho}$ is accepted and $\mathrm{H} 4$ is rejected. So it can be concluded that there is no difference in the average of treynor value between Islamic and conventional mixed mutual funds.

It is known that the significance value (Asymp Sig) of the sharpe calculation of the mixed mutual fund is 0.028 . Because the Significance $<0.05$ then Ho is rejected and H5 is accepted. So it can be concluded that there are differences in the average of sharpe value between Islamic and conventional mixed mutual funds.

It is known that the significance value (Asymp Sig) of the return of mixed mutual funds is 0.174. Because the Significance $>0.05$ then Ho is accepted and H6 is rejected. So it can be concluded that there is no difference in the average of treynor value between Islamic and conventional mixed mutual funds.

\section{Differences in performance of Islamic and conventional fixed income mutual funds}

This different test is conducted to test a number of hypotheses, to find out whether there are differences in performance between Islamic fixed income mutual funds and conventional fixed income mutual funds. The results of the Man-Whitney test are as follows:

It is known that the significance value (Asymp Sig) of the return on fixed income mutual funds is 0.902 . Because the Significance $>0.05$ then $\mathrm{Ho}$ is accepted and $\mathrm{H} 7$ is rejected. So it can be concluded that there is no difference in the average of sharpe value between Islamic and conventional fixed income mutual funds.

It is known that the significance value (Asymp Sig) of the sharpe calculation of fixed income mutual funds is 0.650 . Because the Significance> 0.05 then Ho is accepted and H8 is rejected. So it can be concluded that there is no difference in the average of treynor value between Islamic and conventional fixed income mutual funds.

It is known that the significance value (Asymp Sig) of the return on fixed income mutual funds is 0.821. Because Significance $>0.05$ then Ho is rejected and H9 is accepted. So the conclusion is that there is no difference in the average of sharpe value between Islamic and conventional fixed income mutual funds.

\section{DISCUSSION}

A. Comparison of performance of Islamic and conventional stock mutual funds

The results of testing hypotheses 1 until hypothesis 3 have different significance values. For hypotheses 1 and 3 have a significance value $>0.05$, which means that both hypotheses are rejected. While hypothesis 2 has a significance value $>0.05$ which means that the hypothesis is accepted. So it can be concluded that there are differences in performance between Islamic and conventional stock mutual funds when viewed from the return calculation and Sharpe calculation, whereas for Treynor calculation there is no difference in performance.

Other research showed that testing on Sharpe and Treynor variables, both of which have significant values $>0.05$, which means that there are no significant differences in the performance of Islamic and conventional stock mutual funds [14]. The difference in the results of this research can be caused by differences in periods and differences in the products sampled in the research. In the Jepryanyah and Syariah research used, the period 2011-2013, while this research used the period 2015-2017. On the other hand, the difference in results from the two researches is due to using different benchmarks for market performance. This research is using a single benchmark index, so the benchmark used to measure the performance of stock mutual funds is only based on the IHSG, both for conventional stock mutual funds and Islamic stock mutual funds. While other research used multiple benchmark index, namely the JCI for conventional stock mutual funds and JII (Jakarta Islamic Index) for Islamic stock mutual funds [14].

In contrast to previous research which shows that when using the return and sharpe calculation will show results that there is no significant difference between conventional stock mutual funds and Islamic stock mutual funds [11]. However, if calculated based on treynor and jensen calculations, it will show there are differences between the two categories. Differences can be caused due to different research periods and types of mutual funds, although both use the same method, namely different test of independent sample test. However, in previous research [11], before hypotheses testing using the independent sample $\mathrm{t}$ test, first do an F-test or homogeneity test. While in this research, after the normality test, a hypothesis test is carried out immediately.

Other research also showed that there was no significant difference between the performance of Islamic and conventional stock mutual funds based on treynor calculations, which were tested using the Paired Samples T Test [12]. On the other hand, there are significant differences between the performance of Islamic and conventional stock mutual funds, using the M2 Measure approach during the 2012-2015 period. During this period, the performance of Islamic stock mutual funds with the M2 Measure approach was one of the best. Some differences between those research and this research are because the two researches have different research periods, and use different methods. The method used in the research conducted by Nurul Huda was the paired samples T test and M2 Measure approach. While this research using a different test independent sample $\mathrm{T}$ test. Therefore the results obtained will also be different [12] 


\section{B. Comparison of performance of Islamic and conventional mixed mutual funds}

The results of hypothesis tests 4-6 have different significance values. For hypotheses 4 and 6 have significance values $>0.05$, namely 0.257 and 0.174 . It means that there is no difference in performance between Islamic mixed mutual funds and conventional mixed mutual funds using returns and treynor. However, the performance using Sharpe calculation has a significance of $<0.05$, which is 0.028 . This concludes that there are differences between the performance of Islamic and conventional mixed mutual funds.

The results of this research are similar to other research [23]. The research explained that the performance of mixed mutual funds using the Sharpe calculation has a significance of $<0.05$, which means there is a difference between a mixed mutual fund of foreign and local managers. While the performance calculated using other methods has a significance $>0.05$ which means the hypothesis is rejected and there is no significant difference between the two mutual funds. Although the results of the two research are relatively the same, the object of the research is clearly different. In this research, the object under study was a comparison between the performance of mutual funds with foreign and local investment managers, while in this research the comparison is the performance of Islamic and conventional mutual funds.

Other research [14] also contradicts with this research. The research shows that there are no significant differences between conventional and Islamic mutual funds, both using the calculation of Sharpe, Treynor, and Jensen. While in this research, there is one that has a significant difference, namely by using the Sharpe method. This difference is caused by differences in the research period between the two studies. Besides that, because the number of mutual fund objects used is different, it has different results.

\section{Comparison of performance of Islamic and conventional fixed income mutual funds}

Test results of hypothesis 7,8,9 all have a significance value $>0.05$. So that it shows that there is no significant difference between the performance of Islamic and conventional fixed income mutual funds, whether based on the calculation of return, sharpe, or treynor.

This is in accordance with the research [14],[24],[25] which show that there is no significant difference between conventional and Islamic fixed income mutual funds using either the sharpe, treynor, or jensen calculations. One of the factors that causes this is because all the mutual fund products analyzed are both domiciled in Indonesia, which means the same market conditions, so they have risks that are not much different. The calculation of return does not use the risk calculation in it, and the sharpe calculation is only the risk of the portfolio used. That means that for these types of mutual funds do not use market risk in the calculation.

In contrast to the research that there is a significant difference between Islamic mutual funds and conventional mutual funds based on Treynor calculations [26]. This difference can occur because the securities forming portfolios in mutual funds that do not have differences experience considerable pressure, so that in general the performance of the mutual funds has decreased significantly. In addition, it can also be influenced by investor behavior that responds negatively to the weakening factors of domestic and global macroeconomic conditions which are indicated by a rise in the BI rate or interest rate. As well as a shift in the orientation of market participants that exceeds foreign exchange as a reserve to pay off debt.

\section{CONCLUSION}

The results of data analysis obtained from this research can be summarized as follows. The results of different tests on stock mutual funds show that based on the calculation of returns and sharpe there is a difference between Islamic and conventional stock mutual funds. Whereas when viewed from treynor calculation there is no difference. The results of different tests on mixed mutual funds show that there is a significant difference between Islamic mixed mutual funds and conventional mixed mutual funds when viewed from the sharpe calculation. However, when viewed based on the calculation of return and treynor there is no difference between Islamic and conventional mixed mutual funds. The results of different tests on fixed income mutual funds show that, overall, there is no significant difference between islamic fixed income mutual funds and conventional fixed income mutual funds when viewed based on the return, sharpe, and treynor calculation.

In the category of stock mutual funds, types of conventional stock mutual fund are superior to Islamic stock mutual funds when viewed based on the calculation of returns and sharpe. However, if using treynor calculations, Islamic stock mutual funds are superior to conventional stock mutual funds. In the category of mixed mutual funds, types of conventional mixed mutual funds are better than Islamic mixed mutual funds when viewed based on the calculation of sharpe and treynor. While Islamic mutual funds are superior when viewed from the calculation of the average return. In the category of fixed income mutual funds, conventional fixed income mutual funds are superior to Islamic income mutual funds when viewed from all types of calculations, both based on return, sharpe, and treynor calculation. So it can be said that conventional mutual funds are more superior than Islamic mutual funds. It can be seen from the value of return, sharpe, and treynor in conventional mutual funds that are higher than Islamic mutual funds for all types, whether they are stock, mixed or fixed income mutual funds.

Further research is needed in analyzing the performance of a mutual fund by using samples, observation periods, and different and more performance appraisal methods so that performance appraisals will provide more accurate results for long-term investment decisions.

\section{REFERENCES}

[1] D. K. Musto, "The Economics of Mutual Funds", Annual Review of Financial Economics, vol. 3, pp. 159-172, 2011. Available: https://www.jstor.org/stable/42940423

[2] D.K. Malhotra, M. Jaramillo \& R. Martin, "Mutual Fund Governance, Returns, Expenses, and Cash Flows", Quarterly Journal of Finance and Accounting, vol. 50, No. 3/4, pp. 52-86, 2014. Available: https://www.jstor.org/stable/23646114

[3] H. Merdad,M. K. Hassan \& M. Khawaja, "Does Faith Matter in Mutual Funds Investing? Evidence from Saudi Arabia", Emerging Markets Finance and Trade, vol. 52, no. 4, pp. 938-960, 2016 , doi:10.1080/1540496X.2015.1025655 
[4] A. G.F. Hoepner, H. G. Rammal \&M. Rezec, "Islamic mutual funds' financial performance and international investment style: Evidence from 20 countries", The European Journal of Finance, vol. 17, no. 9-10, pp. 829850, 2011. doi:10.1080/1351847X.2010.538521

[5] Z. R. Rao, M. Z. Tauni, \& A. Iqbal, "Comparison between Islamic and General Equity Funds of Pakistan: Difference in Their Performances and Fund Flow Volatility," Emerging Economy Studies, vol. 1, no. 2, pp. 211-226, 2015. doi:10.1177/2394901515599273

[6] A. S. Haerisma, "Pengantar Reksa Dana Syariah (Introduction of Islamic Mutual Fund)", Al Amwal, vol. 6, no. 2, pp. 1-16, 2014. doi: 10.24235/amwal.v6i2.261

[7] B. N. Lehmann \& D. M. Modest, "Mutual Fund Performance Evaluation: A Comparison of Benchmarks and Benchmark Comparisons", The Journal of Finance, vol. 42, no. 2, Jun 1987, pp. 233-265. doi: 10.1111/j.1540-6261.1987.tb02566.X

[8] M. Grinblatt \& S. Titman, "A Study of Monthly Mutual Fund Returns and Performance Evaluation Techniques", The Journal of Financial and Ouantitative Analysis, vol. 29, no. 3, Sep 1994, pp. 419-444. doi: 10.2307/2331338

[9] D. Moreno \& R. Rodríguez, "The value of coskewness in mutual fund performance evaluation", Journal of Banking \& Finance, vol. 33, no. 9, Sep 2009, pp. 1664 1676. doi: 10.1016/j.jbankfin.2009.03.015

[10] J. Huang, C. Sialm \& H. Zhang, "Risk Shifting and Mutual Fund Performance", The Review of Financial Studies, vol. 24, no. 8, Aug 2011, pp. 2575-2616. Available: https://www.jstor.org/stable/20869318

[11] M. Agussalim, N. Limakrisna, \& H. Ali, "Mutual Funds Performance: Conventional and Sharia Product", International Journal of Economics and Financial Issues, vol. 7, no. 4, pp. 150-156, 2017. Available: https://www.econjournals.com/index.php/ijefi/article/vi ew/5085

[12] N. Huda \& K. Hudori, "Analisis Perbandingan Kinerja Reksa Dana Saham Syariah Dan Konvensional Periode 2012-2015", Jurnal Kajian Ekonomi dan Bisnis Islam Iqtishadia, vol. 10, no. 2, pp. 184-209, 2017. doi: 10.21043/iqtishadia.v10i2.2242

[13] E. Hidayatul, L., Suhadak, \& S. Sulasmiyati, “Analisis Perbandingan Kinerja Reksadana Syariah dan Reksadana Konvensional (Studi Pada Reksadana Yang Terdaftar Di Otoritas Jasa Keuangan Periode 20122016)", Jurnal Administrasi Bisnis (JAB), vol. 35, no. 2 , pp. 114-121, $2016 . \quad$ Available: http://administrasibisnis.studentjournal.ub.ac.id/index.p hp/jab/article/view/1376/1763

[14] J. Putra \& S. Fauzie, "Analisis Perbandingan Kinerja Reksa Dana Konvensional Dengan Reksa Dana Syariah di Indonesia", Jurnal Ekonomi dan Keuangan, vol. 2, no. 5, pp. 282-295, 2014. Available: https://jurnal.usu.ac.id/index.php/edk/article/view/1168 $6 / 5044$

[15] M. Riyadi, M. Heykal, \& T. Indrawati, "Analisis Perbandingan Reksa Dana Saham Syariah Dengan Reksa Dana Saham Konvensional Periode 2009-2012", Journal Binus Business Review, vol. 5, no. 1, pp. 230' 240, $2014 . \quad$ Available: http://journal.binus.ac.id/index.php/BBR/article/viewFil e/1212/1080

[16] Isnurhadi, "Analisis Kinerja Reksadana Saham Dengan Ihsg Dan Equity Fund Index Sebagai Benchmarking Serta Pengaruhnya Terhadap Perubahan Jumlah Asset Under Management Dan Unit Penyertaan", Jurnal Manajemen dan Bisnis Sriwijaya, vol. 2, no. 3, pp. 194208, 2014. Available: http://eprints.unsri.ac.id/4732/3/MAKALAH_ISNURH ADI_JMBS.pdf

[17] M. Q. Acma, "Comparative Study on Performance Evaluation of Mutual Fund Schemes in Bangladesh: An Analysis of Monthly Returns", Journal of Business Studies Quarterly, vol. 5, no. 4, pp. 190-209, 2014.
Available: http://jbsq.org/wpcontent/uploads/2014/06/June_2014_13.pdf

[18] M. Jakšić, M. Leković, \& M. Milanović, "Measuring the Performance of Mutual Funds - a Case Study", Industidja, vol. 43, no. 1, pp. 37-51, 2015. doi: 10.5937/industrija43-6677

[19] S. Agarwal \& N. Mirza, "A Study On The Risk-Adjusted Performance Of Mutual Funds Industry in India", Review on Innovation and Competitiveness, vol. 3, no. 1, pp. 75-94, $2017 . \quad$ Available: https://hrcak.srce.hr/file/266883

[20] R.B. Bajracharya, "Mutual fund Performance in Nepalese Mutual fund units: An analysis of Monthly Returns", Jounal of Advance Academic Research, vol. 3, no. 2, pp. 92-100, 2016. doi: 10.3126/jaar.v3i2.16758

[21] M. B. Alexandri, M. Pragiwani, \& D. Laiela, "Performance of Sharia Mutual Fund: The Analysis of Asset Allocation in Indonesia", Mediterranean Journal of Social Sciences, vol. 8, no. 3, pp. 163-169, 2017. doi: 10.5901/mjss.2017.v8n3p163

[22] R. Bauer, K. Koedijk, \& R. Otten, "International Evidence on Ethical Mutual Fund Performance and Investment Style", Journal of Banking \& Finance, vol. 29, pp. 1751-1767, $2005 . \quad$ doi: 10.1016/j.jbankfin.2004.06.035

[23] B. P. B. Putra \& I. Mawardi, "Perbandingan Kinerja Reksadana Syariah Di Indonesia Menggunakan Metode SHARPE (Studi Kasus Reksadana Syariah Saham, Reksadana Syariah Pendapatan Tetap dan Reksadana Syariah Campuran periode 2012-2014)", Jurnal Ekonomi Syariah Teori dan Terapan, vol. 3, no. 9, pp. 683-698, Sep 2016. doi: 10.20473/vol3iss20169pp683698

[24] V. Ratnawati \& N. Khairani, "Perbandingan Kinerja Reksadna Syariah Dan Reksadana Konvensional", Jurnal Akuntansi Universitas Riau, vol. 1, no. 1, pp. 96113, $2012 . \quad$ Available: https://ja.ejournal.unri.ac.id/index.php/JA/article/view/1 459

[25] F. R. Zamzany \& E. Setiawan, "Studi Komparatif Kinerja Reksadana Saham Konvensional dan Syariah Di Indonesia", Akuntabilitas: Jurnal Ilmu Akuntansi, vol. 11, no. 2, pp. 305-318, 2018. doi: 10.15408/akt.v11i2.8794

[26] T. Rustendi, “Analisis Kinerja Reksa Dana Pendapatan Tetap, Reksa Dana Saham, dan Reksa Dana Campuran (Studi di Bursa Efek Indonesia - BEI)", Jurnal Ekonomi Manajemen, vol. 3, no. 2, Nov 2017, pp. 83-95. doi: $10.37058 / \mathrm{jem} . \mathrm{v} 3 \mathrm{i} 2.329$ 